\title{
Immunoassay of tear lysozyme in conjunctival diseases
}

\author{
D. K. SEN AND G. S. SARIN
}

From the Department of Ophthalmology, Maulana Azad Medical College, Lok Nayak Jai Prakash Narain Hospital, and Guru Nanak Eye Centre, New Delhi, India.

SUMMARY The tear lysozyme content in 111 normal subjects and in 159 patients with various conjunctival diseases was determined by a single radial immunodiffusion technique. Tear lysozyme level in normal people was $1.33 \mathrm{mg} / \mathrm{ml}$. (SI conversion: $\mathrm{mg} / \mathrm{ml}=\mathrm{g} / \mathrm{l}$.) The mean tear lysozyme levels in patients with chronic irritative conjunctivitis $(0.97 \mathrm{mg} / \mathrm{ml})$ and nutritional deficiency with epithelial xerosis $(0.76 \mathrm{mg} / \mathrm{ml})$ were significantly lower than in the normal controls. The mean tear lysozyme levels in tears from patients with vernal conjunctivitis $(1.20 \mathrm{mg} / \mathrm{ml})$, phlyctenular conjunctivitis $(1.10 \mathrm{mg} / \mathrm{ml})$, and acute bacterial conjunctivitis $(1.48 \mathrm{mg} / \mathrm{ml})$ were not significantly different from those in the normal controls. Superimposition of acute bacterial conjunctivitis on trachoma did not alter the low tear lysozyme level that existed before in these patients.

Lysozyme (muramidase) is present in high concentration in normal human tears. Its role is uncertain. In view of the bacteriolytic property of lysozyme ${ }^{12}$ it has generally been held that the enzyme in tears acts as a protective agent against bacterial infection.

Although there are several studies on the tear lysozyme level in keratoconjunctivitis sicca,${ }^{3-10}$ only a few are available on it in other conjunctival diseases. ${ }^{11-13}$ The tear lysozyme level in patients with trachoma is low. ${ }^{14}$ The purpose of the present study was 2-fold: (1) To investigate whether there is any alteration in the tear lysozyme level in patients with other conjunctival diseases, and (2) To investigate whether superimposition of acute bacterial conjunctivitis in patients with trachoma alters the existing low tear lysozyme level.

\section{Subjects and methods}

The study was carried out among 159 patients with various conjunctival diseases and 111 healthy people chosen consecutively from the Outpatient Department of Guru Nanak Eye Centre, New Delhi. The latter group served as control for all the disease groups and comprised people who had no ocular or systemic disease and had attended the hospital only for a routine check-up.

An earlier report by the present authors has already

Correspondence to Dr D. K. Sen, V/4, MAM College Campus, Kotla Road, New Delhi-110 002, India. described the lysozyme level among normal Indian people by the immunoassay method. ${ }^{14}$ However, for the purpose of the present investigation it was considered advisable to examine a fresh group of normal people to serve as concurrent control. The diagnosis of conjunctival diseases was based on detailed clinical examination, including slit-lamp biomicroscopy, ophthalmoscopy, and relevant bacteriological and other laboratory investigations. The patients with chronic irritative conjunctivitis were factory workers whose eyes were exposed to noxious fumes for many months. Their chief complaints were watering, burning, stinging, foreign body sensation, and an urge to

Table 1 Pathogenic organisms identified on culture in cases of acute bacterial conjunctivitis

\begin{tabular}{lll}
\hline $\begin{array}{l}\text { Pathogenic } \\
\text { organisms } \\
\text { identified }\end{array}$ & $\begin{array}{l}\text { Acute bacterial } \\
\text { conjunctivitis* } \\
(28 \text { cases) }\end{array}$ & $\begin{array}{l}\text { Trachoma with } \\
\text { acute bacterial } \\
\text { conjunctivitist } \\
(20 \text { cases) }\end{array}$ \\
\hline Staphylococcus aureus & 14 & 13 \\
Pneumococcus & 8 & 5 \\
Pseudomonas pyocyanea & 6 & 3 \\
Streptococcus viridans & 5 & 3 \\
Streptococcus pyogenes & 4 & 4 \\
Proteus vulgaris & 3 & 2 \\
Klebsiella pneumoniae & 2 & 0 \\
Escherichia coli & 1 & 3 \\
Alpha-haemolytic streptococci & 2 & 1 \\
\hline * More than one organism was isolated in 18 patients. \\
+More than one organism was isolated in 12 patients.
\end{tabular}


Table 2 Age and sex distribution of healthy subjects and patients with conjunctival diseases

\begin{tabular}{|c|c|c|c|c|c|c|c|c|}
\hline Sex & Normal & $\begin{array}{l}\text { Epithelial } \\
\text { xerosis }\end{array}$ & $\begin{array}{l}\text { Vernal } \\
\text { conjunctivitis }\end{array}$ & $\begin{array}{l}\text { Phlyctenular } \\
\text { conjunctivitis }\end{array}$ & $\begin{array}{l}\text { Acute } \\
\text { bacterial } \\
\text { conjunctivitis }\end{array}$ & $\begin{array}{l}\text { Chronic } \\
\text { conjunctivitis }\end{array}$ & Trachoma & $\begin{array}{l}\text { Trachoma } \\
\text { acute bacterial } \\
\text { conjunctivitis }\end{array}$ \\
\hline Male & 55 & 15 & 10 & 13 & 17 & 13 & 16 & 11 \\
\hline Female & 56 & 10 & 7 & 5 & 11 & 7 & 15 & 9 \\
\hline Total & 111 & 25 & 17 & 18 & 28 & 20 & 31 & 20 \\
\hline \multicolumn{9}{|l|}{ Age (yr) } \\
\hline$\leq 15$ & 20 & 16 & 5 & 14 & 3 & 0 & 2 & 2 \\
\hline $16-30$ & 37 & 9 & 12 & 4 & 13 & 9 & 10 & 8 \\
\hline $31-45$ & 26 & 0 & 0 & 0 & 11 & 11 & 16 & 8 \\
\hline$\geq 46$ & 28 & 0 & 0 & 0 & 1 & 0 & 3 & 2 \\
\hline Total & 111 & 25 & 17 & 18 & 28 & 20 & 31 & 20 \\
\hline
\end{tabular}

rub their eyes. Hyperaemia of the conjunctiva was a prominent clinical feature and was particularly marked in the area of the palpebral aperture. On slit-lamp examination there were no follicles, scarring of the conjunctiva, or associated corneal lesions. The pathogens identified on conjunctival smears and cultures in cases of acute bacterial conjunctivitis are given in Table 1 . The bacterial infection was mixed in majority of the patients.

A general physical examination was made in every patient, and those who had no ocular or systemic affliction other than the conjunctival disease were chosen. None of the patients received any medication before or at the time of the study.

Stimulated tear samples of 100 to $200 \mu \mathrm{l}$ were collected by a method described previously ${ }^{15}$ and stored at $-20^{\circ} \mathrm{C}$ until assayed. Lysozyme was quantified by a single radial immunodiffusion technique originally described by Mancini et al. ${ }^{16}$ after diluting the tear samples 1:25 with phosphate buffered saline $(\mathrm{pH}$ $7 \cdot 4$ ). The technique has been described in detail. ${ }^{14}$ Monospecific rabbit antihuman lysozyme serum and the reference standard were obtained from Behring Institute, West Germany. A standard curve was constructed for each plate and the concentration of lysozyme in tear samples was determined with reference to the standard curve.

\section{Results}

The age and sex distribution of normal people and the patients are given in Table 2. Tear lysozyme was found in all the samples in measurable quantity. In normal people the overall mean value of tear lysozyme was $1.33 \pm 0.69 \mathrm{mg} / \mathrm{ml}$. (SI conversion: $\mathrm{mg} / \mathrm{ml}=\mathrm{g} / \mathrm{l}$.) There was no significant difference $(t=1 \cdot 07, \mathrm{DF} 109$, $\mathrm{p}>0.30)$ between the levels in males $(1 \cdot 41 \pm 0 \cdot 70$ $\mathrm{mg} / \mathrm{ml})$ and that in females $(1 \cdot 27 \pm 0.67 \mathrm{mg} / \mathrm{ml})$. The tear lysozyme levels in the different age groups are shown in Table 3. It can be seen that the lysozyme level was low in the young, rose with age, and started falling after the age of 30 years. Since the tear lysozyme level in normal people varied with age, it was necessary for comparison to take separate controls matched for age from among the normal people for each disease group.

The mean levels of tear lysozyme in controls matched for age and in the disease groups are given in Table 4 . The mean tear lysozyme was significantly decreased in the cases of nutritional deficiency with epithelial xerosis $(p<0 \cdot 01)$ and in chronic irritative conjunctivitis $(p<0 \cdot 001)$ as compared with normal healthy people of the respective age groups. It was not significantly altered in vernal conjunctivitis, phlyctenular conjunctivitis, and acute bacterial conjunctivitis. The mean tear lysozyme in patients with trachoma with superimposed acute bacterial conjunctivitis was compared with that in patients with trachoma after matching for age, and the difference failed to attain statistical significance $(p>0 \cdot 05)$.

\section{Discussion}

The techniques employed for the estimation of tear lysozyme were difficult for routine application and for comparison, and the values obtained varied widely. ${ }^{451718}$ Bonavida and Sapse ${ }^{19}$ introduced a method based on the bacteriolytic action of lysozyme on the cell wall of Micrococcus lysodeikticus. Johansson and Malmquist ${ }^{20}$ observed that the bacteriolytic

Table 3 Distribution of tear lysozyme level in the various age groups in normal subjects

\begin{tabular}{llll}
\hline $\begin{array}{l}\text { Age } \\
\text { (years) }\end{array}$ & $\begin{array}{l}\text { No. of } \\
\text { subjects }\end{array}$ & $\begin{array}{l}\text { Mean } \pm S D \\
(\mathrm{mg} / \mathrm{ml})\end{array}$ & $\begin{array}{l}\text { Coefficient of } \\
\text { variation (\%) }\end{array}$ \\
\hline$\leq 15$ & 20 & $0 \cdot 83 \pm 0 \cdot 34$ & $41 \cdot 0$ \\
$16-30$ & 37 & $1 \cdot 64 \pm 0 \cdot 73$ & $44 \cdot 5$ \\
$31-45$ & 26 & $1 \cdot 45 \pm 0 \cdot 62$ & $42 \cdot 8$ \\
$\geq 46$ & 28 & $1 \cdot 24 \pm 0 \cdot 63$ & $50 \cdot 8$ \\
\hline
\end{tabular}

SI conversion: $\mathrm{mg} / \mathrm{ml}=\mathrm{g} / \mathrm{l}$. 
Table 4 Tear lysozyme levels in controls matched for age and those in patients with conjunctival diseases

\begin{tabular}{|c|c|c|c|c|c|c|}
\hline \multirow{3}{*}{$\begin{array}{l}\text { Disease } \\
\text { groups }\end{array}$} & \multirow{3}{*}{$\begin{array}{l}\text { Number of } \\
\text { patients } \\
\text { and normal } \\
\text { controls }\end{array}$} & \multicolumn{4}{|c|}{ Lysozyme in $\mathrm{mg} / \mathrm{ml}$} & \multirow[b]{3}{*}{$t$} \\
\hline & & \multicolumn{2}{|l|}{ Disease groups } & \multicolumn{2}{|l|}{$\begin{array}{l}\text { Normal controls } \\
\text { matched for age }\end{array}$} & \\
\hline & & Mean $\pm S D(S E)$ & $C V \%$ & Mean $\pm S D(S E)$ & $C V \%$ & \\
\hline $\begin{array}{l}\text { Epithelial xerosis } \\
\text { Vernal conjunctivitis } \\
\text { Phlyctenular conjunctivitis } \\
\text { Acute bacterial conjunctivitis } \\
\text { Chronic irritative conjunctivitis } \\
\text { Trachoma }\end{array}$ & $\begin{array}{l}25 \\
17 \\
18 \\
28 \\
20 \\
31\end{array}$ & $\begin{array}{l}0 \cdot 76 \pm 0 \cdot 44(0 \cdot 09) \\
1 \cdot 20 \pm 0 \cdot 60(0 \cdot 15) \\
1 \cdot 10 \pm 0 \cdot 69(0 \cdot 16) \\
1 \cdot 48 \pm 0 \cdot 66(0 \cdot 12) \\
0 \cdot 97 \pm 0 \cdot 46(0 \cdot 10) \\
0 \cdot 89 \pm 0 \cdot 36(0 \cdot 07)\end{array}$ & $\begin{array}{l}57 \cdot 9 \\
50 \cdot 0 \\
62 \cdot 7 \\
44 \cdot 6 \\
47 \cdot 4 \\
40 \cdot 4\end{array}$ & $\begin{array}{l}1 \cdot 20 \pm 0 \cdot 64(0 \cdot 13) \\
1 \cdot 18 \pm 0 \cdot 66(0 \cdot 16) \\
0 \cdot 98 \pm 0 \cdot 51(0 \cdot 12) \\
1 \cdot 47 \pm 0 \cdot 59(0 \cdot 11) \\
1 \cdot 81 \pm 0 \cdot 81(0 \cdot 18) \\
1 \cdot 52 \pm 0 \cdot 75(0 \cdot 13)\end{array}$ & $\begin{array}{l}53 \cdot 3 \\
55 \cdot 9 \\
52 \cdot 0 \\
40 \cdot 1 \\
44 \cdot 8 \\
49 \cdot 3\end{array}$ & $\begin{array}{l}2 \cdot 87<0.01 \\
0 \cdot 09>0.90 \\
0 \cdot 61>0.50 \\
0 \cdot 09>0 \cdot 90 \\
4 \cdot 03<0 \cdot 001 \\
4 \cdot 19<0.01\end{array}$ \\
\hline Trachoma & & & & $\begin{array}{l}\text { Trachoma patients } \\
\text { matched for age } \\
\text { as control }\end{array}$ & & \\
\hline $\begin{array}{l}\text { Trachoma with acute } \\
\text { bacterial conjunctivitis }\end{array}$ & 20 & $1 \cdot 06 \pm 0 \cdot 47(0 \cdot 10)$ & $44 \cdot 3$ & $0 \cdot 83 \pm 0 \cdot 38(0 \cdot 09)$ & $45 \cdot 8$ & $1 \cdot 70>0 \cdot 05$ \\
\hline
\end{tabular}

$\mathrm{CV}=$ coefficient of variation.

SI conversion: $\mathrm{mg} / \mathrm{ml}=\mathrm{g} / \mathrm{l}$.

lysozyme determination is not a specific enzyme assay and is probably influenced to some extent by factors other than the lysozyme activity. To avoid such influences tear lysozyme levels were measured by a single radial immunodiffusion method.

Anderson ${ }^{13}$ studied cases of epithelial xerosis and found the tear lysozyme to be much lower. Present findings are in agreement with his observations. Thompson and Gallardo ${ }^{12}$ and Harada and associates $^{21}$ have shown that the chief sources of lysozyme in tears is the lacrimal gland rather than the mucous gland of the conjunctiva. It is therefore assumed that the cases of nutritional deficiency with epithelial xerosis have a decreased production of the enzyme by the lacrimal gland.

Ridley' reported a low level of lysozyme in tears in phlyctenular conjunctivitis and considered it to be due to associated excessive tearing. However, recent studies have shown that there is no correlation between the titre of lysozyme in the tear fluid and the rate of tear flow. ${ }^{891122}$ We did not find the tear lysozyme level in this disease to be significantly different from that of healthy subjects.

Erickson and associates ${ }^{18}$ reported the tear lysozyme level to be low in eyes exposed to industrial fumes. The present findings are similar. This low level may be due to destruction of lysozyme in the conjunctival sac or to binding of the lysozyme locally to the tissue by noxious agents. ${ }^{11}$

Reports on the tear lysozyme level in patients with acute bacterial conjunctivitis are contradictory. ${ }^{4122324}$ Some authors have reported a low level of tear lysozyme in these patients and attributed this to excessive tearing associated with the disease. ${ }^{43}$ It has already been pointed out that excessive tearing does not alter the lysozyme level in tears. ${ }^{891122}$ Janke and associates $^{24}$ on the other hand observed that the lysozyme level was probably slightly higher in acute bacterial conjunctivitis. Gordon and associates ${ }^{25}$ and McClelland and van Furth ${ }^{26}$ have demonstrated that the neutrophils contain lysozyme which is liberated from them during degeneration and cell death. Therefore the lysozyme content of tears from patients with acute bacterial conjunctivitis may be expected to be high. However, no significant alteration was found in the tear lysozyme level in such patients as compared with controls. This indicates that the neutrophils present in tears of such patients are not numerous enough to contribute significantly to the lysozyme content of tears.

The tear lysozyme levels in patients with trachoma have been reported to be low. ${ }^{14}$ This low lysozyme level in patients with trachoma probably makes them more vulnerable to secondary bacterial infections, which are frequently associated with trachoma. Ridley ${ }^{27}$ had stated that while the normal lysozyme content of tears might be effective against some pathogenic bacteria, the lysozyme level needed to be decreased only very slightly to be totally ineffective against all pathogens. A group of patients with trachoma were examined as concurrent controls for the group of patients with trachoma superimposed with acute bacterial conjunctivitis. There was no significant difference in the tear lysozyme levels between the 2 groups. This again suggests that acute bacterial conjunctivitis does not alter the lysozyme level in tears significantly.

We thank Mr G. P. Mathur, statistician, New Delhi Tuberculosis Centre. New Delhi, for the statistical analysis of the data. 


\section{References}

1 Ridley F. Lysozyme. an antibacterial body present in great concentration in tears, and its relation to infection of the human eye. Proc $R$ Soc Med 1928; 21: 1495-506.

2 Neu HC, Dreyfus J. Canfield RE. Effect of human lysozyme on Gram positive and Gram negative bacteria. Antimicrob Agents Chemother 1968: 442-4.

3 Meyer K. Mucopolysaccharides and mucoids of ocular tissues and their enzymatic hydrolysis. In: Sorsby A. ed. Modern Trends in Ophthalmologv. London: Butterworth, 1948; 2: 71-8.

4 Regan E. The lysozyme content of tears. Am J Ophthalmol 1950; 33: 600-5.

5 McEwen WK. Kimura SJ. Filter paper electrophoresis of tears. I. Lysozyme and its correlation with keratoconjunctivitis sicca. Am J Ophthalmol 1955; 39 (suppl): 200-2.

6 van Bijsterveld OP. Diagnostic tests in the sicca syndrome. Arch Ophthalmol 1969; 82: 10-4.

7 Mukai M. Tear proteins. Low molecular proteins and lysozyme. Nippon Ganka Gakkai Zasshi (Tokyo) 1975; 79: 607-13.

8 Mackie IA. Seal DV. Quantitative tear lysozyme assay in units of activity per microlitre. Br J Ophthalmol 1976; 60: 70-4.

9 Avisar R, Menache R, Shaked P, Rubinstein J, Machtey I, Savir $H$. Lysozyme content of tears in patients with Sjögren's syndrome and rheumatoid arthritis. Am J Ophthalmol 1979; 87: 148-51.

10 Mackie IA, Seal DV. The questionably dry eye. Br J Ophthalmol 1981: 65: 2-9.

11 Sapse AT. Bonavida B. Stone W Jr., Sercarz EE. Human tear lysozyme. III. Preliminary study on lysozyme levels in subjects with smog eye irritation. Am J Ophthalmol 1968; 66: 76-80.

12 Thompson R, Gallardo E. The concentration of lysozyme in the tears in acute and chronic conjunctivitis: with a note on the source of lysozyme in tears. Am J Ophthalmol 1936; 19: 684-5.

13 Anderson O. Acta Paediatr Scand 1932; 14: 81. Cited by Thompson R. Lysozyme and the antibacterial properties of tears. Arch Ophthalmol 1941; 25: 491.

14 Sen DK. Sarin GS. Immunoassay of human tear lysozyme. Am J Ophthalmol 1980; 90: 715-8.

15 Sen DK. Sarin GS. Mani K. Saha K. Immunoglobulin in tears of normal Indian people. Br J Ophthalmol 1976; 60: 302-4.

16 Mancini G., Carbonera AO. Heremans JF. Immunochemical quantitation of antigens by single radial immunodiffusion. Int $J$ Immunochem 1965; 2: 235-54.

17 Miglior M. Comite PD. Regnetti E. Riesame del l'attivita lisozimica delle lacrime umane normale. In: Second International Symposium on Fleming's Lysozyme. Milan: Società Prodotti Antibiotici, 1961.

18 Erickson OF. Feeney L. McEwen WK. Filter paper electrophoresis of tears. Animal tears and presence of 'slow moving lysozyme'. Arch Ophthalmol 1956; 55: 800-6.

19 Bonavida B. Sapse AT. Human tear lysozyme. II. Quantitative determination with standard Schirmer strips. Am J Ophthalmol 1968; 66: 70-6.

20 Johansson BG. Malmquist J. Quantitative immunochemical determination of lysozyme (muramidase) in serum and urine. Scand J Clin Lab Invest 1971; 27: 255-61.

21 Harada M. Miyata M. Ishikawa S. Antibacterial substances in human tears. Jpn J Ophthalmol 1980; 24: 320-7.

22 Ronen D. Eylan E, Romano A. Stein R, and Modan M. A spectrophotometric method for quantitative determination of lysozyme in human tears: description and evaluation of the method and screening of 60 healthy subjects. Invest Ophthalmol Visual Sci 1975; 14: 479-84.

23 Cavaka V. Prica M. Uber Lysozymwirkung in normalen und pathologischen Augensekretion. Albrecht von Graefes Arch Klin Ophthalmol 1929; 121: 740.

24 Janke $W$, Langmaack $H$, Tiburtius $H$. Bestimmung der lysozymalen Aktivitat der Tranenflussigkeit mit klinisch anwendbaser Methode. Klin Monatsbl Augenheilkd 1973; 163: 366-9.

25 Gordon S. Todd J, Cohn ZA. In vitro synthesis and secretion of lysozyme by mononuclear phagocytes. J Exp Med 1974; 139: $1228-48$.

26 McClelland DBL, van Furth $R$. In vitro synthesis of lysozyme by human and mouse tissues and leucocytes. Immunology 1975; 28: 1099-114.

27 Ridley F. The tears. In: Ridley F. Sorsby A. eds Modern Trends in Ophthalmology. New York: Hoeber, 1940: 382-7. 